\title{
Community Economic Development Prospect Based on Wakaf Funds
}

\author{
Ida Martinelli ${ }^{1}$, Asliani Harahap ${ }^{2}$, Zainuddin ${ }^{3}$ \\ ${ }^{I}$ Faculty of Social and Political Science of Universitas Muhammadiyah Sumatera Utara (UMSU), Medan, \\ Indonesia \\ ${ }^{2,3}$ Lecturer at Law Faculty of Universitas Muhammadiyah Sumatera Utara (UMSU), Medan, Indonesia \\ idamartinelli1964@gmail.com
}

\begin{abstract}
Wakaf is a philanthropic institution that is quite old in Islamic history. The purpose of the existence of wakaf is not only just taqarrub to Allah SWT, but also gives the economic impact of wakaf objects. Wakaf is one of the solutions given by Allah to eliminate the gap between rich and poor people. Indeed wakaf has a very high economic potential in the welfare of the people. Through cash wakaf or wakaf cash investment in wakaf property in the form of plantations and others indicates that Islam does not leave its people in poverty. Based on this, the wakaf should no longer be oriented towards mosques, madrassah, burial ground, but rather towards a more productive direction producing new economic resources intended for the welfare of the people.
\end{abstract}

Keywords: Ecomonic development; community; wakaf funds.

\section{Introduction}

The Qur'an, which forms the basis of all Islamic law, firmly states that Allah is the owner of everything in the world, while humans are the Khalifah of Allah on earth. Allah created everything not for Himself, but submitted to humans as caliphs on earth. According to M.A. Mannan, all human beings collectively are allowed to own, enjoy and transfer the wealth that is recognized and maintained in Islam. ${ }^{1}$

The first provision in Sharia regarding ownership is that property is prohibited from being owned except for exploitation. The act of owning property and not being enjoyed if carried out by every individual in the community will cause disruption to productivity and the economy. ${ }^{2}$

A serious problem facing the world today is the distribution of economic wealth fairly and equally. The unfair economic distribution causes the maintenance of poverty throughout the ages. According to Taqiyuddin An-Nabhani's view, that poverty that must be solved is poverty that afflicts individuals so that what must be done is to guarantee the fulfillment of their basic needs and encourage them to meet their secondary and tertiary needs, and the way to achieve it is to create a fair economic distribution in the midst of middle of people's lives. ${ }^{3}$

According to the Islamic economic system, the core of the economic problem is not lack of production, but rather the problem of distribution. Maliki stated that the economic problem is not the lack of available resources, because those resources are sufficiently provided by Allah SWT, but lies in how to distribute those resources to all people. Because, no matter how many goods and services are available, without the right distribution patterns, and consumption restrictions, there will still be problems of shortages for others. ${ }^{4}$

Policies that only rely on economic growth are policies that limit the circulation of assets among the rich people. The basic aim of Islam in the economic field is to bring happiness $($ falah) to its adherents in the world and in the hereafter, and to realize brotherhood

\footnotetext{
${ }^{1}$ M. Sholahuddin. 2007. Asas-Asas Ekonomi Islam. Jakarta: PT RajaGrafindo Persada, p. 128.

${ }^{2}$ Ibid, pp. 129.

${ }^{3}$ Uce K. Suganda. 2007. Islam \& Penegakkan Ekonomi Yang Berkeadilan. Bandung: Iris Press, p. 14.

${ }^{4}$ Gusfahmi. 2007. Pajak menurut Syariah. Jakarta: PT RajaGrafindo Persada, p. 49.
} 
among members of the Muslim community (ummah)..$^{5}$ This goal cannot be achieved if the distribution of wealth among members of the Muslim community is unfair; the gap between the rich and the poor is very wide and conflicts between classes occur in society.

Based on this reality, the Islamic economic system tries to enforce the rules of equitable distribution of wealth among members of the Muslim community by taking very effective action. Wealth must not form a circle among the rich, but must remain in circulation among all members of society and meet the needs of all people. ${ }^{6}$ To realize a fair, honest and equitable distribution of wealth, Islam prescribes positive and prohibitive actions.

One of the instruments of distribution of economic wealth in Islam is wakaf. Wakaf in Islam includes philanthropic institutions along with zakat, infaq, alms. The purpose of wakaf is to play a role in eradicating poverty, misery, sickness, illiteracy, so as to create an equitable distribution of wealth. ${ }^{7}$ Indeed the potential for wakaf is very large to change the face of poverty in Indonesia, especially in North Sumatra. Unfortunately, this great potential is largely devoted to only one aspect, namely for the construction of mosques, madrassah or burial grounds. There is almost no thought to see the economic potential possessed by a very large wakaf.

Based on these facts, and then came the idea to make a cash wakaf, so besides if there are Muslims who want to contribute not only to land, but also wakaf money that can be utilized economic value in order to improve the welfare of Muslims.

Based on the aforementioned thoughts, it is interesting to study related to the prospects for the economic development of the cash wakaf-based community in North Sumatra.

\section{Review of Literature}

\subsection{Wakaf: definition and legal basis}

Wakaf according to Arabic means al-habsu, which comes from the verb habasayahbisu-habsan, meaning to keep people away from something or imprison. ${ }^{8}$ Then this word develops into habbasa and means to consecrate wealth because of Allah. Wakaf in another sense is stop. ${ }^{9}$ If the word al-habsu is associated with property such as land, animals and others, it means the freezing of property rights for certain benefits. ${ }^{10}$

Rasulullah SAW used the word al-habs (withhold) that is to hold a property whose benefits are used for virtue and are encouraged by religion. ${ }^{11}$ Abu Bakar al-Jabir al-Jazayri said that the definition of withholding as the definition of wakaf means that it cannot be inherited, it cannot be sold, and it cannot be traded. ${ }^{12}$ Imam Abu Hanifah interpreted wakaf

\footnotetext{
${ }^{5}$ Muhammad Sharif Chaudrhry. 2012. Sistem Ekonomi Islam Prinsip Dasar. Jakarta: Kencana Prenada Media Group, p. 77.

${ }^{6}$ Ibid.

${ }^{7}$ Ibid, p. 92.

${ }^{8}$ Rachmadi Usman. 2009. Hukum Perwakafan Di Indonesia. Jakarta: Sinar Grafika, p 51.

${ }^{9}$ Ahsin W. Alhafidz. 2013. Kamus Fiqh. Jakarta: AMZAH, p. 236.

${ }^{10}$ Andri Soemitra. 2010. Bank \& Lembaga Keuangan Syariah. Jakarta: Kencana Prenada Media Group. Cet. Ke-2, p. 433.

${ }^{11}$ Mahmud Yunus Daulay dan Nadlrah Naimi. 2012. Studi Islam 2. Medan: Ratu Jaya, p. 224.

${ }^{12}$ Didin Hafidhuddin. 2006. Mutiara Dakwah Mengupas Konsep Islam Tentang Ilmu, Zakat \& Ekonomi Syariah. Jakarta: Albi Publishing, p. 290.
} 
by holding ,ain (principal) assets with permanent status that belonged to waqif and offering their benefits for good. Based on this definition, Imam Abu Hanifah positions wakaf as almsgiving whose position is like ,,ariyah (borrow and borrow). ${ }^{13}$

As a term in Islamic sharia, wakaf is defined as retaining property rights over material objects (al-,,ain) for the purpose of giving away their benefits or benefits (almanfaeeah). ${ }^{14}$ Malikiyah Ulema defines wakaf which is to make the benefit of wakif property in the form of rent or proceeds such as dirhams (money) for people who are entitled to certain sighat for a certain period of time in accordance with the wishes of the wakaf. ${ }^{15}$

According to Article 1 of Law Number 41 Year 2004 concerning Wakaf, wakaf is a legal act of wakif to separate and / or surrender a portion of his property to be used forever or for a certain period in accordance with his interests for the purposes of worship and / or general welfare according to sharia. According to Abdurrahman wakaf is a religious institution that can be used as a means for the development of religious life, especially for Muslims who are Muslim in order to achieve spiritual and material welfare towards a just and prosperous society based on Pancasila. ${ }^{16}$

Wakaf is not explicitly mentioned in the Qur'an, but verses that can be used as a basis for the implementation of wakaf are contained in several verses. First in Surah al-Hajj verse 77, which means:

Meaning: O you who have believed, bow and prostrate and worship your Lord and do good - that you may succeed. (Surah al-Hajj verse 77)

Secondly in Surah al-Baqarah verse 267, which means:

Meaning: O you who have believed, spend from the good things which you have earned and from that which We have produced for you from the earth. And do not aim toward the defective there from, spending [from that] while you would not take it [yourself] except with closed eyes. And know that Allah is Free of need and Praiseworthy.( Surah al-Baqarah verse 267)

The third surah Ali Imran verse 92, which means:

Meaning: Never will you attain the good [reward] until you spend [in the way of Allah] from that which you love. And whatever you spend-indeed, Allah is Knowing of it. (surah Ali Imran verse 92)

The legal basis for wakaf in the hadith of the Prophet, peace be upon him, namely: ${ }^{17}$

Meaning: "From Abu Hurairah r.a. verily the Messenger of Allah said: When the child of Adam (man) dies, his deeds will end except for three cases,

\footnotetext{
${ }^{13}$ Nurul Huda dan Mohamad Heykal. 2010. Lembaga Keuangan Islam Tinjauan Teoritis dan Praktis. Jakarta: Kencana Prenada Media Group, p. 309.

${ }^{14}$ Andri Soemitra, Loc.Cit.

${ }^{15}$ Rozalinda. 2014. Ekonomi Islam Teori dan Aplikasinya pada Aktivitas Ekonomi. Jakarta: PT RajaGrafindo Persada, p. 224.

${ }^{16}$ Abdurrahman. 1990. Masalah Perwakafan Tanah Milik Dan Kedudukan Tanah Wakaf Di Negara Kita. Bandung: PT. Citra Aditya Bakti. Cet. ke-3, p. 1.

${ }^{17}$ Suhrawardi K. Lubis. 2010. Wakaf \& Pemberdayaan Umat. Jakarta: Sinar Grafika bekerja sama dengan UMSU Publisher, p. 18.
} 
sadaqah jariyah, useful knowledge, and a pious child who prays for his parents ". (H.R. Muslim).

Then another hadith, which means: ${ }^{18}$

Meaning: "From Ibn Umar, he said:" Umar told the Prophet Muhammad, I have a hundred dirhams of shares in Khaibar, I have never gotten the treasure that I admire most like that, but I offered it. The Holy Prophet said to Umar: hold it (do not sell, grant or inherit the origin of the principal) and make alms to sabilillah ". (H.R. Bukhari and Muslim)

According to the perspective of Islamic Jurisprudence, for the existence of wakaf must be fulfilled 4 (four) pillars or elements of the wakaf, namely:

a. There are people who have wakaf (as a wakaf subject) known as wakaf;

b. The existence of objects that are represented (mauquf bih) as wakaf objects;

c. The existence of wakaf recipient (as a subject of wakaf) is Nazhir.

d. The existence of a contract or lafaz or statement of submission of wakaf from the wakaf hand to the person or place of representation (mauquf ,,alayh). ${ }^{19}$

In Law Number 41 of 2004 concerning Wakaf there are additional elements or pillars of wakaf, namely:

a. There are people who receive assets that are represented from wakaf as wakaf managers;

b. There is a wakaf period (specific time).

Wakaf conditions are:

a. Wakaf is valid forever, not limited by a certain time;

b. The purpose of wakaf must be clear, for example to endow a plot of land to the mosque;

c. Wakaf must be carried out immediately after there is permission from the endowment;

d. Wakaf is a case that must be carried out in the absence of khiyar (canceling or carrying out the endowments that have been declared) because the statement of endowments applies immediately and forever. ${ }^{20}$

Wakaf element in Article 6 of Law No. 41 of 2004 as follows:
a. Wakif;
b. Nazhir;
c. Wakaf property;
d. Pledge of Wakaf;
e. Allotment of properties benga wakaf;
f. Duration of wakaf.

\footnotetext{
${ }^{18}$ Ibid., p. 19.

${ }^{19}$ Rachmadi Usman, Op.Cit., p. 59.

${ }^{20}$ Mahmud Yunus Daulay dan Nadlrah Naimi, Op.Cit., p. 230.
} 
Based on Article 1 of Law No. 41 of 2004 concerning Endowments that:

Paragraph 2: Wakif is the party that makes a donation of their property.

Paragraph 3:The Endowment Pledge is a statement of the will of the endowment which is pronounced verbally and / or written to Nazhir to donate his property.

Paragraph 5: Endowment Property is property that has long-lasting durability and / or long-term benefits and has economic value according to sharia represented by the Wakaf.

The purpose and function of wakaf is stated in two articles, namely in Article 4 of Law no. 41 of 2004 reads: endowments aiming at utilizing endowment property in accordance with their functions. Then in Article 5 it says: endowments function to realize the potential and economic benefits of endowments for worship purposes and to promote public welfare.

The two articles above clearly show that the wakaf law desires that wakaf property can be utilized in accordance with its function, namely realizing economic potential and benefits, in the framework of increasing the quality and quantity of human relations to God (hablun minallahi) and with wakaf the expected welfare of life people can become better, so that there is a relationship between the endowment (wakaf) with the recipient of wakaf (maukuf), which in Islam is called hablun minannasi. ${ }^{21}$

To support the purpose of this endowment, Article 22 of Law Number 41 Year 2004 concerning Wakaf is stated:

"In order to achieve the goals and functions of wakaf, the properties of wakaf can only be designated for:

a. religious facilities and activities;

b. educational and health facilities and activities;

c. assistance to the poor, neglected children, orphans, scholarships;

d. progress and improvement of the people's economy; and / or

e. other public welfare advancements that are not in conflict with sharia and statutory regulations.

According to Mundzir Qahaf, in the purpose of endowments are prescribed the following matters:

1. For the sake of goodness, such as:

a. Helping public or special education foundations, professional groups, IslaM foundations, public or special libraries.

b. Helping students and students to study at home and abroad.

c. Helping Islamic scientific research foundations.

d. Take care of orphans, widows and weak people.

e. Take care of elderly parents and help foundations that provide services to them.

f. Protect children, mothers and weak families.

g. Helping the poor and all families who earn a mediocre income.

h. Providing technical training and workshops for those who need to increase their income.

\footnotetext{
${ }^{21}$ Didin Hafidhuddin, Op. Cit., p. 291.
} 
i. Providing public services in the form of water and electricity, health services, crossings and others in cities and villages.

j. Assist lighting of roads and alleys that are passed by people and vehicles.

k. Providing financial assistance with light conditions to small entrepreneurs who need additional capital.

1. Forming mosque priests, preachers and people guarding the mosque.

$\mathrm{m}$. Building mosques and providing equipment, as well as filling it with Al-Qur'an

Manuscripts and books, also provided for the needs of the mosque.

n. Forming health development projects and sick people.

o. Give material assistance to the wakif or his family or neighbors and all those who are under his responsibility, even if they do not need it.

p.Helps maintain animals and the environment and general cleanliness.

q. Establish funding to eradicate crime.

r. Repairing roads both in cities and villages, especially those that have not become government projects.

s. Establish all efforts that lead to the defense of the state and society.

t. Forming funding of da'wah both at home and abroad.

u. Or others from various forms of good deeds; both general and special.

2. Not for immoral purposes which are forbidden by the Shari'a, or any applicable law or tradition.

3. Does not conflict with applicable laws and traditions. ${ }^{22}$

\subsection{Community-Based Economic Development Wakaf Funds}

Wakaf is a part of Islamic law that is specifically regulated in Indonesian laws and regulations. Thus, wakaf is one of the Islamic legal institutions that has become positive law in Indonesia. As a religious institution, in addition to functioning as worship to Allah, wakaf also functions socially. In its function as worship, wakaf is expected to be a provision for the life of wakaf (endowment) in the hereafter because the reward will continue to flow as long as the endowments are utilized. As for its social function, wakaf is a very valuable asset in development. Its role in the distribution of welfare among the people and poverty reduction is one of the goals of wakaf. Wakaf if properly managed it will greatly support development, both in the economic, religious, social, cultural, political and defense and security fields. In various countries whose representation is well developed, wakaf is one of the economic pillars that can be used to improve people's welfare.

The development of wakaf property can be interpreted by rebuilding the destroyed wakaf or rebuilding and repairing the damaged ones, this development is an old problem experienced by wakaf since long time ago. The second development can be interpreted by expanding the existing endowments or adding new endowments to the old endowments that affect the initial purpose of endowments. Starting from here, the role of Nazhir in managing wakaf property is vital because it has full authority in managing wakaf property in an effort to advance and develop wakaf property. Nazhir is a general leader in wakaf, therefore a Nazhir must have noble character, trustworthiness, good behavior, experience in mastering the science of administration and finance which is deemed necessary to carry out his duties according to the type of wakaf and its purpose.

\footnotetext{
${ }^{22}$ Mundzir Qahaf, 2005. Manajemen Wakaf Produktif. Jakarta: KHALIFA, p.199.
} 
Article 43 paragraph (2) Explanation of Law Number 41 of 2004 concerning Endowments is stated:

"Management and development of wakaf property are carried out productively, among others by way of collection, investment, investment, production, partnership, trade, agribusiness, mining, industry, technology development, building construction, apartments, flats, supermarkets, shops, shops, offices, educational facilities or health facilities and businesses that are not in conflict with sharia ".

In Chapter V Article 42 of the Wakaf Law, it states that Nazhir is required to manage and develop wakaf property in accordance with its purpose, function and designation.

Article 43 states that:

1. Management and development of wakaf property by Nazhir as referred to in Article 42 shall be carried out in accordance with Sharia principles.

2. Management and development of wakaf property as referred to in paragraph (1) shall be carried out productively.

3. In the case of management and development of wakaf property as referred to in paragraph (1) a guarantor is required, a sharia guarantor institution is required. Article 44 states that:

"In the management and development of wakaf property, it is prohibited to make changes to the allotment of wakaf property except on the basis of written permission from the Indonesian Wakaf Board".

Wakaf is a very important part of Islamic law. Wakaf has a braided relationship between spiritual life with the socio-economic field of Muslim society. Wakaf in addition to the dimension of Divine ubudiyah, it also functions socially. Wakaf worship is a manifestation of one's solid sense of faith and a high sense of solidarity with fellow human beings. Wakaf as the glue of the relationship, hablum minallah wa hablum minannas, a vertical relationship to God and a horizontal relationship to fellow human beings.

When compared with other social institutions above, the characteristics of wakaf lie in the preservation of substances or property values that are represented by the use of the results for the needs of people or institutions in need. Compared to zakat which is restricted to certain groups (asnaf al-samaniah), then wakaf has potential that can be further developed because its designation is not limited. In terms of wakif it is also not limited to those from the rich as zakat, so that anyone can become a wakif. It is appropriate if the wakaf institution is given special attention in order to unravel the problems of society especially those related to the economy. Herein lies the importance of developments in wakaf based on Islamic legal principles to realize benefit. ${ }^{23}$

From the facts above wakaf is directed for the purpose of sustaining productive benefits. Land for mosques, date palm gardens for the needs of the community, homes for the educational activities of the people and others. That is why in a modern perspective, wakaf is considered as Islamic philanthropy. Philanthropy is a voluntary action in the public interest

$$
2014 \text {, p. } 2 .
$$

${ }^{23}$ Asni, "Pengembangan Hukum Perwakafan Di Indonesia", dalam Jurnal Al- 'Adl, Vol. 7 No.2, Juli 
that is the realization of social justice through certain models to resolve social structure injustice, treat the root causes of injustice and provide advocacy.

Facts of the Islamic history of the Classical era of the Daula Abbasids and the Ottoman Turks, endowments have significantly contributed significantly to the development of the education, social, economic, health and cultural sectors. Unfortunately, the current model of wakaf empowerment has not received serious attention. In Indonesian society, in general wakaf is only intended for religious institutions such as the construction of mosques, madrasah and even what is quite strange is for burial grounds. Why is it still very rare, endowments intended as a source of capital for the economic development of the people? This is among the problems of wakaf as a consequence of understanding which is not yet proportional. $^{24}$

The rigidity of understanding that endowments are only limited to fixed objects that do not move has made the endowments of sharia not develop as they should. Likewise, the management system is not directed and without a model, it has made the use of wakaf property neglected, even it causes maintenance costs and is consumptive. Though the great potential of wakaf property is very sufficient to eradicate poverty of Muslims for decades.

Wakaf is one of the potential Islamic institutions to be developed, especially in developing countries. Based on the experience of developing countries whose wakaf institutions have advanced, wakaf can be used as one of the economic pillars. In general in these countries, wakaf is managed productively. Productive management of wakaf has actually been done since the beginning of Islam, so at that time wakaf could be used to empower the people.

The discussion on the development of wakaf objects shows two things: First, the wakaf object has provisions in various fiqh books with diverse opinions and in various laws and regulations established by the government, and secondly, the development of technology and human civilization encourage changes in perspective which impact on the expansion of the meaning of assets (al-amwal), so that the development of wakaf objects is understood as an expansion of the scope of wakaf objects that have been explained by the ulama before. ${ }^{25}$ Wakaf, Infaq, alms and Zakat are basically potential and strategic Islamic economic institutions for the economic development of the Ummah. Unfortunately, these strategic potentials have not been optimally utilized.

In the perspective of the Qur'an the ideal management of wakaf property in addition to considering the necessity from an economic and business perspective, it must have a social effect that is the public interest (mashlahat lil 'ammah). Social factors that become priority parameters include; in what fields property is developed, independently or in cooperation, if the cooperation to which party is invested, and so on.

Some considerations in the management and development of wakaf property are most directed towards;

\footnotetext{
${ }^{24}$ Winoto Soekarno, "Pengembangan Wakaf Sebagai Sumber Modal Usaha”, www.academia.edu. , diakses tanggal 22 November 2016 pukul 12.35 WIB.

${ }^{25}$ Hamzah, "Pengembangan Makna Obyek Wakaf dalam Fiqih Islam dan Hukum Positif di Indonesia (Kajian tentang Perluasan dan Kewenangan Peradilan Agama dalam Menyelesaikan Sengketa Wakaf)" melalui www.badilag.net., diakses tanggal 29 November 2016 pukul 12.26 WIB.
} 
1. The benefit of society at large. Property is a medium so that humans can obtain glory in the sight of Allah SWT by providing benefits to themselves and others in need.

2. The management and development model must be in the sharia corridor or recommended.

3. Property is not a focus of concentration solely on management and development, but must affect the distribution of benefits, namely the distribution of people's welfare.

4. Management and development of property cannot be separated from the concept of worship. $^{26}$

Seeing the development of wakaf in Indonesia, especially the city of Medan which tends to be stagnant in terms of the development of wakaf property as an object of business, it needs to be explored further the reasons for the stagnation of the development of the wakaf object. Not yet optimal implementation of wakaf so far among Muslim communities may be influenced by various reasons, namely:

1. The position of wakaf which is only a sunnah worship so that the motivation for its implementation is not so strong. This reason is actually quite logical because even if the sunnah worship is not like an endowment, zakat alone as a compulsory worship has not been optimized so far.

2. The use of wakaf assets for the community is not yet clear, so it may be that some people still doubt the direction and target of the assets represented. This is closely related to the management of wakaf that has not been optimal.

3. The understanding of wakaf is still limited. That most Muslims understand wakaf in the traditional form, which is limited to certain assets (immovable objects) such as land or buildings so that it automatically limits the opportunities for people to make a contribution. In the minds of the general public, endowments only apply to those who have excess property in the form of land or buildings. ${ }^{27}$

Of course the lack of optimal empowerment or empowerment or development of wakaf objects is one of them due to the lack of knowledge of the cloud community about the benefits and actual goals of wakaf that are related to the legal development of wakaf property or wakaf objects.

One of the concrete and easy forms in an effort to make wakaf a basis for development, improving the economy of the people is through the endowment of money. Money has a very strategic position in economic traffic. Today, money does not only function as a medium of exchange, but is already considered to be part of an object that can be traded. Therefore, some scholars do not hesitate to designate money as an object of wakaf with the term cash wakaf, wakaf al-nukud, which in Indonesian is translated with money wakaf, and some others translate it with cash wakaf. ${ }^{28}$

\footnotetext{
${ }^{26}$ Winoto Soekarno, "Pengembangan Wakaf Sebagai Sumber Modal Usaha", www.academia.edu. , diakses tanggal 22 November 2015 pukul 12.35 WIB.

${ }^{27}$ Asni, "Pengembangan Hukum Perwakafan Di Indonesia", dalam Jurnal Al- 'Adl, Vol. 7 No.2, Juli 2014 , p. 2.

${ }^{28}$ Suhrawardi K. Lubis, dkk. Op. Cit., p.103.
} 
Endowments of movable objects in the form of money are carried out by the wakif through Islamic financial institutions appointed by the Minister (Article 28 UUW). Wakaf for movable objects in the form of money is carried out by a waqif in writing to the manager of the Sharia Financial Institution (LKS). Then the certificate of money wakaf was issued, and then the money wakaf certificate that was issued was submitted by the LKS to the Wakif and Nazhir as proof of the surrender of the wakaf property (Article 29 UUW). Furthermore, in Government Regulation No. 42 of 2006 emphasized the mechanism of wakaf for movable objects in the form of money. In this regulation it is stated that the endowment of money that can be represented is the rupiah currency, if the money to be represented is still in foreign currency, it must be converted first in rupiah currency (Article 22 Government Regulation No. 42 of 2006).

Wakaf in the form of money, is seen as one of the choices that can make wakaf achieve more results, because in this wakaf money, money is not only used as a medium of exchange. More than that, money is a commodity that is ready to produce and is useful for the development of other economic activities. Therefore, like other commodities, endowments of money are also seen to produce something more.

Economically, this endowment has great potential to be developed, because with this endowment model the reach ability and mobilization will be much more evenly distributed among the people compared to the traditional endowment model (endowments in the form of land and buildings), because endowments in the form of land and buildings can only be done by families or individuals who are relatively able (rich) only.

The scope of cash wakaf promises better benefits that can be obtained from wakaf sources in addition to utilizing the results of the management of wakaf, cash wakaf can also expand the endowment of endowments and increase the productivity of endowment assets. Wakaf money can be implemented in various ways, including in the following form:

a. Direct cash endowments, endowments of direct money can be done in two ways, namely: (1) permanent endowments, and (2) futures endowments. Permanent Wakaf, meaning that the money handed over by the Wakaf is a wakaf property for selmanya. In other words, the Wakif cannot be withdrawn. Wakaf futures, the money submitted by the Wakif is only temporary, after a certain period of time the money can be withdrawn by the Wakif. Thus, what is here in Wakif is only the result of investment; usually the nominal endowment wakaf is relatively large.

b. Wakaf shares, in addition to being represented in the form of money which can be categorized as money endowments are endowments in the form of shares, shares are a sign of capital participation in a Limited Liability Company (PT). The benefits obtained from this wakaf share are dividends (profits distributed by the company to shareholders, capital gains ie profits derived from the difference between buying and selling, and non-material benefits, namely the birth of power / voting rights in determining the course of the company.

c. Wakaf takaful, wakaf is implemented with a takaful insurance pattern. For example, a person intends to represent Rp. 100,000,000. - then he enters into a contract with the Sharia Insurance Company, provided that it will be paid periodically for 10 years. If before 10 years the Wakif passed away, at that time the insurance company paid the Wakif endowments to Nazhir who was appointed by the Wakaf. 
d. Tree Wakaf, tree wakaf is carried out with the pattern of endowing a number of certain tree plants, then the money from the sale of the plant's production is used for public benefit. ${ }^{29}$

The management of wakaf funds (cash) as an investment instrument becomes attractive, because the benefits of the investment in the form of investment benefits will be enjoyed by people everywhere (whether local, regional or international). This is possible because the benefits of the investment in the form of cash can be transferred to any beneficiary throughout the world. Investment in endowment funds can be carried out anywhere without borders, given the nature of cash wakaf which is cash that can be invested in any country. ${ }^{30}$

The use of cash wakaf in the form of investment is expected to be able to bridge the gap between the "rich" community and the "poor" community, because it is expected that there will be a transfer of wealth (in the form of investment returns) from the rich to the "poor". This process can become a 'snowball effect' when benefits from endowment funds are reinvested and so on.

According to the Ministry of Religion of the Republic of Indonesia Wakaf funds can also be used to support various activities, both in the field of procurement of Social Good and Private Good. Therefore, the use of funds from the management of wakaf can open opportunities for attractive economic analysis with regard to the allocation of resources within the framework of public finances. Usually, Social Good is defined as goods that can be consumed by various parties, where the parties do not negate / defeat each other (nonrivals), it is difficult to determine the price, and utilization by one person does not reduce the benefits for others. This condition does not apply to Private Good, which can determine the price and expel others from being able to consume it. The nature of consumption is "rival". In other words, the benefits obtained by someone who consumes Social Good is "externalized" where the goods can also be used by others. This is the condition associated with Social Good. Private Good, the benefits of consumption are enjoyed specifically by certain consumers, and as a result of these consuming activities, other people cannot consume them. ${ }^{31}$

Empowerment and development of wakaf property through cash or money wakaf is done productively, among others by way of collection, investment, investment, production, partnership, trade, agribusiness, mining, industry, and technology development, construction of buildings, apartments, flats, supermarkets, supermarkets, shops, educational facilities, or businesses that do not conflict with sharia. ${ }^{32}$

There are several examples in North Sumatra related to wakaf which is intended for the economic development of the ummah, including wakaf assets which are developed for economic empowerment, for example in 2005 the empowerment of one of the mosques as well as economic empowerment was located in the Al-Badar Mosque on Binjai Km Road 6.8 Medan by building the "Al-Badar Center Medan" with financial support from the Ministry of

\footnotetext{
${ }^{29}$ Ibid, p. 111.

${ }^{30}$ Irsyad Lubis, "Prospek Ekonomi Harta Wakaf”, dalam Suhrawardi K. Lubis, Op.Cit., p.110.

${ }^{31}$ Departemen Agama RI. 2006. Peraturan Perundangan Perwakafan. Direktorat Jenderal Bimbingan Masyarakat Islam: Jakarta, p. 146.

${ }^{32}$ Kementerian Agama Republik Indonesia. 2011. Profile Percontohan Wakaf Produktif. Jakarta: Kementerian Agama RI Direktorat Jenderal Bimbingan Masyarakat Islam Direktorat Pemberdayaan Wakaf, p.
} 2. 
Religion amounting to Rp. 2,000,000,000 (two billion rupiah) and Medan Government assistance in the amount of Rp. 4,000,000,000 (four billion rupiah), but it has not functioned as it should due to changes in the physical planning of the building as well as inaccuracy in financial planning and development processes.

Wakaf land of the late Tengku Darwisyah in Perbaungan Serdang Bedagai District covering an area of approximately 51 hectares (47 hectares new in the form of Deed of Substitution Wakaf Pledge (APAIW) is located in Galuh Perbaungan City and 3 more parcels of wakaf certificate are located in Jambur village Perbaungan Island Serdang Bedagai Regency is being prepared to be managed productively. This wakaf land is very possible to be used as an oil palm plantation managed by professional management consisting of trustful experts for the benefit of the people. There is another land on Jln. TASAN Medan (still in the form of the Pledge of Endowment Pledge) which is a very strategic location and has the potential to be built Rusunawa and the UKM Center or halal food.

Wakaf must be developed optimally with productive professional management achieving tangible results in people's lives. The initial step in implementing this productive endowment is to eliminate all obstacles encountered so far in managing endowments, especially the non-productive assets of wakaf, Nazhir who are less professional and administering an irregular management of wakaf. All wakaf assets that have high commercial value are reorganized and the results are for the welfare of the community.

Nazhir was the person most responsible for the wakaf property entrusted to him, both in terms of maintaining the wakaf property, as well as for the results and efforts for its development. Every nazhir activity on wakaf property must be in consideration of the sustainability of wakaf property by channeling its benefits for the benefit of mauquf 'alaih. Therefore, the role of Nazirs is not only to mobilize wakaf funds and directly spend them as alms, but to make them into assets first, then to manage them productively and then to use the proceeds as alms. ${ }^{33}$

Nazhir was the person most responsible for the wakaf property entrusted to him, both in terms of maintaining the wakaf property, as well as for the results and efforts for its development. Every nazhir activity on wakaf property must be in consideration of the sustainability of wakaf property by channeling its benefits for the benefit of mauquf 'alaih. Therefore, the role of Nazir is not only to mobilize wakaf funds and directly spend them as alms, but to make them into assets first, then to manage them productively and then to use the proceeds as alms.

There are 2 (two) things that need to be done for the development of wakaf property from the nazhir wakaf $\operatorname{side}^{34}$ :

a. kenazhiran management. The thing that must be considered is the professionalism of Nazir, both regarding:

(1) credibility is related to honesty,

(2) professionalism related to capabilities, as well

(3) compensation related to utilization fees as a professional implication,

\footnotetext{
${ }^{33}$ Tiswarni, "Peran Nazhir Dalam Pemberdayaan Wakaf (Tinjauan Terhadap Strategi Pemberdayaan Wakaf Badan Wakaf Alquran Dan Wakaf Center)", melalui www.ejournal.radenintan.ac.id, diakses tanggal 18 Desember 2016 pukul 14.35 WIB

${ }^{34}$ Ibid.
} 
b. allocation of wakaf assets. The possibility of a change of function (change of designation) and relocation becomes the necessity that must be done for the development of wakaf assets which may also be affected by market mechanisms that affect the needs for the allocation of wakaf assets to be more productive.

Related to the problem of the management of wakaf property, that wakaf Nazhir does not stand alone. Nazhir wakaf has a relationship with the Indonesian Wakaf Board (hereafter written BWI). One of BWI's tasks is to foster Nazhir that already exists throughout Indonesia. BWI together with the Ministry of Religion oversees the management of wakaf throughout Indonesia by making policies that lead to improving Nazhir capabilities so that they can manage their endowments productively.

To avoid the failure of investment / development of the wakaf object absolutely necessary, it must be managed using proportional planning. Planning is nothing other than utilizing the objects of representation systematically to achieve certain goals by paying attention to the changing needs of society and values of life.

Representation is the main tool in the distribution of assets and wealth of the people. Through representation, it is hoped that economic resources will not only be concentrated on the rich, but will also be distributed to those who really need it.

There are some things that absolutely need to be considered in the development of wakaf property, namely:

a. Data collection or inventory of representative objects that contain information about the shape of wakaf objects, location of wakaf objects, utilization of wakaf objects, nazhir or wakaf managers, nazhir work programs and others relevant to this.

b. Short, medium and long term planning. This plan should be relevant to the work program in the socio-economic field in a broad sense, so that a description of the amount of funds needed for each program can be obtained and some funds that may be generated through the empowerment of wakaf objects productively.

c. By paying attention to the potential of wakaf objects, the priority of their utilization can be determined. Is it more beneficial for educational and social purposes or is it managed economically so that the wakaf objects will provide added value from the wakaf institution. Or maybe a combination strategy can be adopted, harvesting some wakaf objects can be used productively for community economic development.

d. In the utilization and development of wakaf objects it is necessary to apply contemporary management principles in accordance with Islamic teachings, meaning that the wakaf objects must be professionally managed by professional managers.

To optimize the function of representation, with social and economic orientation, the state and the public (private) need to participate. State participation, especially the provision of facilities and wakaf arrangements that provide encouragement and motivation to optimize the goals of the wakaf. However, so far no laws and regulations have been found regarding the use of wakaf land for economic purposes (profitability).

The development of wakaf property, especially in the form of land, especially the productive ones, is not enough just with a good will and program, but more than that is needed sufficient financial support. For this reason, intelligence, intelligence and good relations with several institutions are needed to provide financial support; for example the Government, Islamic banks, ZIS, IDB, NGOs and others. 
Support for strict and responsible supervision is also very necessary in developing the management of this wakaf property. Supervision can be from the outside, but even more important is from within alone. This is all intended so that things that are not wanted-and usually as the most acute illness in the management of endowments-do not occur. This is also a step to support the implementation of the wakaf law which also includes criminal sanctions for violations in the management of wakaf property.

Management and development of wakaf property carried out productively can be done in various ways. The productive categories that can be carried out include: collection, investment, investment, production, partnership, trade, agribusiness, mining, industry, technology development, building construction, apartments, flats, supermarkets, shops, offices, offices, educational facilities, facilities health, businesses that do not conflict with sharia.

The great potential of developing wakaf property actually provides various alternatives for Nazhir wakaf to be more creative for the development of wakaf property. The development of the wakaf property itself must also see which side is more profitable to be used as an investment, of course with careful calculation in consultation with the Indonesian Wakaf Board as well as experts in certain fields with mature business calculations. A mature business calculation can minimize the failure of developing and managing wakaf property.

\section{Conclusion}

Quantitatively the number of Muslims living below the poverty line is actually quite a lot scattered throughout the archipelago. This poverty portrait certainly contributes to the reduction in the number of Muslims with reliable resource qualifications. Actually, Allah SWT has provided an institution to eradicate the poverty emergency, through philanthropic institutions such as zakat, infaq, alms and endowments. All philanthropic institutions are not only oriented to worship, but also a form of social concern for Muslims will be fellow. Example of several countries that have succeeded in exploiting the economic potential of wakaf, be it cash, productive business, investment, and then it becomes a necessity for Muslims in Indonesia to not be ashamed and hesitate to "plagiarize" these countries for a rool model of economic use of wakaf. Some inhibiting factors such as the understanding of some Muslims who are still confined to the paradigm of classical centric fiqh thinking, that wakaf is only on objects, should be educated with an understanding of Islam that is modern, humanist, and has social responsibility.

\section{References}

Abdurrahman. 1990. Masalah Perwakafan Tanah Milik Dan Kedudukan Tanah Wakaf Di Negara Kita. Bandung: PT. Citra Aditya Bakti. Cet. ke-3.

Ahsin W. Alhafidz. 2013. Kamus Fiqh. Jakarta: AMZAH.

Andri Soemitra. 2010. Bank \& Lembaga Keuangan Syariah. Jakarta: Kencana Prenada Media Group. Cet. Ke-2.

Departemen Agama RI. 2006. Peraturan Perundangan Perwakafan. Direktorat Jenderal Bimbingan Masyarakat Islam: Jakarta.

Didin Hafidhuddin. 2006. Mutiara Dakwah Mengupas Konsep Islam Tentang Ilmu, Zakat \& Ekonomi Syariah. Jakarta: Albi Publishing.

Gusfahmi. 2007. Pajak menurut Syariah. Jakarta: PT RajaGrafindo Persada. 
Kementerian Agama Republik Indonesia. 2011. Profile Percontohan Wakaf Produktif. Jakarta: Kementerian Agama RI Direktorat Jenderal Bimbingan Masyarakat Islam Direktorat Pemberdayaan Wakaf.

Mahmud Yunus Daulay dan Nadlrah Naimi. 2012. Studi Islam 2. Medan: Ratu Jaya.

Muhammad Sharif Chaudrhry. 2012. Sistem Ekonomi Islam Prinsip Dasar. Jakarta: Kencana Prenada Media Group.

Mundzir Qahaf, 2005. Manajemen Wakaf Produktif. Jakarta: KHALIFA.

Nurul Huda dan Mohamad Heykal. 2010. Lembaga Keuangan Islam Tinjauan Teoritis dan Praktis. Jakarta: Kencana Prenada Media Group.

Rachmadi Usman. 2009. Hukum Perwakafan Di Indonesia. Jakarta: Sinar Grafika.

Rozalinda. 2014. Ekonomi Islam Teori dan Aplikasinya pada Aktivitas Ekonomi. Jakarta: PT RajaGrafindo Persada.

Sholahuddin, M. 2007. Asas-Asas Ekonomi Islam. Jakarta: PT RajaGrafindo Persada.

Suhrawardi K. Lubis. 2010. Wakaf \& Pemberdayaan Umat. Jakarta: Sinar Grafika bekerja sama dengan UMSU Publisher.

Uce K. Suganda. 2007. Islam \& Penegakkan Ekonomi Yang Berkeadilan. Bandung: Iris Press.

\section{Journal}

Asni, "Pengembangan Hukum Perwakafan Di Indonesia", dalam Jurnal Al- 'Adl, Vol. 7 No.2, July 2014.

Syaddan Dintara Lubis, et.al., "Hubungan Hukum Pengelolaan Wakaf Antara Nazhir Dan Badan Wakaf Indonesia Provinsi Sumatera Utara Terhadap Tanah Wakaf Yang Belum Terdaftar (Studi di Kota Medan)”, dalam USU Law Journal, Vol. $3^{\text {rd }}$ November 2015.

Tiswarni, "Peran Nazhir Dalam Pemberdayaan Wakaf (Tinjauan Terhadap Strategi Pemberdayaan Wakaf Badan Wakaf Alquran Dan Wakaf Center)", melalui www.ejournal.radenintan.ac.id, diakses tanggal $18^{\text {th }}$ December 2016 at 14.35 WIB.

Hamzah, "Pengembangan Makna Obyek Wakaf dalam Fiqih Islam dan Hukum Positif di Indonesia (Kajian tentang Perluasan dan Kewenangan Peradilan Agama dalam Menyelesaikan Sengketa Wakaf)".www.badilag.net., accessed on November 29 ${ }^{\text {th }}, 2016$ at 12.26 WIB.

Winoto Soekarno, "Pengembangan Wakaf Sebagai Sumber Modal Usaha", www.academia.edu. , accessed on $22^{\text {nd }}$ November 2015 at 12.35 WIB. 